\title{
The resilience process in family caregivers of people with malignant neoplasia
}

\author{
O processo de resiliência em cuidadores familiares de pessoas com neoplasia maligna \\ El proceso de resiliencia en cuidadores familiares de personas con neoplasia maligna
}

Lucimar Aparecida dos Santos ${ }^{1}(1)$

Patrícia Peres de Oliveira ${ }^{1}(\mathbb{D}$

Edilene Aparecida Araújo da Silveira ${ }^{1}$ (D)

Elaine Cristina Rodrigues Gesteira ${ }^{1}$ (1)

Deborah Franscielle da Fonseca ${ }^{1}$ (D) Andrea Bezerra Rodrigues ${ }^{2}($ )

1. Universidade Federal de São João del-Rei. Divinópolis, MG, Brasil.

2. Universidade Federal do Ceará.

Fortaleza, CE, Brasil.
Corresponding author:

Patrícia Peres de Oliveira.

E-mail: pperesoliveira@ufsj.edu.br

Submitted on $02 / 13 / 2019$.

Accepted on 05/07/2019.

DOI: 10.1590/2177-9465-EAN-2019-0023

\section{Abstract}

Objective: To unveil the resilience process in family caregivers of people with malignant neoplasia. Method: Descriptive and qualitative research performed between September and November of 2017 in a Brazilian Unit of High Complexity Care in Oncology. Individual interviews and four focus groups were conducted with 29 family caregivers. Socio-constructivist methodology was used under Vygotsky's perspective, the theoretical framework of the construction of the resilience processes, besides the hybrid model of thematic analysis. Results: Three thematic categories emerged: "feelings revealed through colors"; "practice of care and communication in the process of resilience" and "faith and hope in the process of resilience". The family caregivers organized themselves to provide support to their family member with malignant neoplasia and they faced, in a more consolidated way, the overwhelming transformations imposed by the disease. Conclusion and implications for practice: The guidelines made by health professionals were paramount in the process of family caregivers' resilience, in addition to emotional support and spirituality. The communication with health professionals is essential in the coping of family caregivers when dealing with problems or conflicts, since there is better conduction in the process of illness of the loved one, when there is greater knowledge and understanding of the disease.

Keywords: Psychological Resilience; Family; Psychological Adaptation; Neoplasia; Family Relations.

\section{Resumo}

Objetivo: Desvelar o processo de resiliência em cuidadores familiares de pessoas com neoplasia maligna. Método: Pesquisa descritiva, qualitativa, realizada entre setembro e novembro de 2017 em uma Unidade de Assistência de Alta Complexidade em Oncologia (UNACON) brasileira. Realizou-se entrevistas individuais e quatro grupos focais com 29 cuidadores familiares. Utilizou-se a metodologia sócioconstrutivista sob a ótica vygotskiana, o arcabouço teórico da construção dos processos de resiliência, além do modelo híbrido de análise temática. Resultados: Emergiram três categorias temáticas: "sentimentos revelados por meio das cores"; "prática do cuidado e comunicação no processo de resiliência" e "fé e esperança no processo de resiliência". Os cuidadores familiares se organizaram para disponibilizar suporte a seu ente com neoplasia maligna e encararam, de uma maneira mais consolidada, as transformações avassaladoras impostas pela doença. Conclusão e implicações para a prática: Desvelou-se que as orientações realizadas pelos profissionais de saúde foram primordiais no processo de resiliência dos cuidadores familiares, além do suporte emocional e da espiritualidade. A comunicação com os profissionais de saúde é imprescindivel no enfrentamento dos cuidadores familiares ao lidar com problemas ou conflitos, posto que há melhor condução no processo de adoecimento do ente querido, quando há maior conhecimento e compreensão da doença.

Palavras-chave: Resiliência Psicológica; Família; Adaptação Psicológica; Neoplasias; Relações Familiares.

\section{RESUMEN}

Objetivo: Desvelar el proceso de resiliencia en cuidadores familiares de personas con neoplasia maligna. Método: Investigación descriptiva, cualitativa, realizada entre septiembre y noviembre de 2017 en una Unidad de Asistencia de Alta Complejidad en Oncología brasileña. Se realizaron entrevistas individuales y cuatro grupos focales con 29 cuidadores familiares. Metodología socio-constructivista bajo la óptica vygotskiana, marco teórico de la construcción de los procesos de resiliencia, además de modelo híbrido de análisis temático. Resultados: Emergieron tres categorías temáticas: "sentimientos revelados por medio de los colores"; "práctica del cuidado y comunicación en el proceso de resiliencia" y "fe y esperanza en el proceso de resiliencia". Los cuidadores familiares se organizaron para proporcionar apoyo a su ente con neoplasia maligna y enfrentaron, de manera más consolidada, las transformaciones impuestas por la enfermedad. Conclusión e implicaciones para la práctica: Se desveló que las orientaciones realizadas por los profesionales de salud fueron primordiales en el proceso de resiliencia, además de soporte emocional y la espiritualidad. La comunicación con los profesionales de salud es imprescindible en el enfrentamiento al lidiar con problemas o conflictos, puesto que hay mejor conducción en el proceso de enfermedad del ente querido, cuando hay mayor conocimiento y comprensión de la enfermedad

Palabras clave: Resiliencia Psicológica; Familia; Adaptación Psicológica; Neoplasias; Relaciones Familiares. 


\section{INTRODUCTION}

The family structure consists of social and emotional relationships, and what unites a group of individuals as family, are the interpersonal relationships, with emotional, moral, ethical, and social support among their members, regardless of kinship relations. ${ }^{1}$ Frequently, it is not organized to deal with the illness of one of its members. ${ }^{1-2}$ In the case of a diagnosis of malignant neoplasia, the effect on the patient and their family is often overwhelming, since it brings to the surface countless feelings, such as fear and anxiety. ${ }^{1,3}$ In parallel, the treatment is complex, and causes various physical, psychological and social changes. ${ }^{2}$

In this context, health professionals who live with people with malignant neoplasms perceive that this disease has a huge social, economic and emotional impact on the family. ${ }^{2,4-5}$

The way the family faces an illness process of a loved one depends on factors such as their resilience ${ }^{3}$ term designated to describe the ability to minimize conflict or stress situations, having as basic elements flexibility, communication, conflict resolution and the belief system. ${ }^{6-8}$ Therefore, resilience is the capacity to resist to adversity and to use it as a growth factor. ${ }^{7}$ It is stressed that family resilience strengthens the phenomenon of individual resilience, being a functional unit, it may or may not encourage resilience and vulnerability in all members. ${ }^{9-10}$

Health professionals, based on the information gathered on the resilience process, can use their expertise to assist each family in order to ensure holistic assistance and offer a better care $^{6}$, because only in this way family members will be able to minimize conflict or stressful situations. ${ }^{8}$

In view of this scenario, and because there is a gap about this theme, evidenced when performing search in the literature, the following research questions were proposed: How does the process of resilience in family caregivers (FC) of patients with malignant neoplasia occur? What are the resilience strategies used by these family members? What are the vulnerabilities and protection factors present in this resilience process?

It is believed that living is to build an itinerary, and since this study involves families of people diagnosed with malignant neoplasia, it is considered that in the face of this diagnosis, the itinerary is, at times, full of colors, in certain circumstances, black and white, others, technicolor and often mixing themselves in the trajectory of disease and treatment, leaving these patients on the verge of a physiological and emotional abyss and their families in helplessness and suffering. In this way, health professionals are committed to helping them in the coping and empowering during the process of malignant neoplasm illness.

It is thought that those responsible for the care of individuals with malignant neoplasia need to be like eagles, which fly at incredible speed and in a straight line, never in circles, or in sinuous movements, but always precise, determined and certain, saving almost always their cub a few meters from the ground and returning him/her to the safety of the nest. Thus, by unveiling the resilience process in relatives of patients with malignant neoplasia, this study will encourage professionals to be like the eagles in palliative care decisions that involve recovery and preventive aspects in order to live better in the face of the vulnerability imposed by the disease.

Therefore, this research is justified by the importance of knowing the resilience process of family caregivers (FC) of people with cancer in the face of the reflection about their vulnerabilities, coping strategies and their adaptation to adversity.

It is also presumed that this research may contribute to the reflection of future interventions with family members who coexist with the suffering of their loved one's illness, in order to contribute to the process of resilience and more adequate assistance to family and patients.

In view of the above, it was aimed to unveil the process of resilience in family caregivers of people with malignant neoplasia.

\section{METHOD}

This is a descriptive research with a qualitative approach that used the socio-constructivist methodology from Vygotsky's perspective, and the theoretical framework of the construction of the resilience processes, besides the hybrid model of thematic analysis.

It is emphasized that the socio-constructivist perspective was the chosen option due to its principles seek malleability, adaptation and accommodation, as well as show favorable feelings of the link between the researcher and the interviewees, from the interchange between the intuitive and the rational in the exploration of the phenomenon, having as scope the exactness, simultaneous to the constructivism, besides considering the person as a social, historical and motivating being or transformer of the scenario where he/she is inserted. ${ }^{9}$

Within the premises of Vygotsky's socio-constructivism, the ideas of transformation and change are used as an interpretative tool, giving possibility to the development of the research, while emphasizing a greater understanding and analysis of the mental health of the familiar caregivers of people with malignant neoplasia and creating a space for the work of psychology, as a propeller of individual and collective knowledge. ${ }^{9}$

Regarding the theoretical framework of the resilience process of family caregivers of people with malignant neoplasia, it is known that resilience allows the recognition of the aspects that support individuals to preserve the good mental disposition even in an inhospitable space and that contributes to a physical and emotional exhaustion. ${ }^{8}$ In this way, the resilience process contributes to quality of life and mental health. The study of the process of resilience take away the central point in the disorders, since it emphasizes the positive and healthy points of view of the individuals, which are essential for a fruitful experience..$^{8-10}$

Thus, this study sought to contribute, through methodology and in the theoretical framework of resilience, to the participation of the research informants in a unique way, and that valued the important parts of the process, such as risk factors and protection factors. In this way, the construction of resilience took place according to the construction of each one present in this 
process, because the "resilient being" is imbued with the unique characteristics of each being, and it is necessary to understand all the stressors that appear throughout the research in order to provide the necessary intervention to each individual. ${ }^{10-11}$

The project was submitted to the ethics and research committee of the hospital scenario of the study of the partner institution, opinion number $2,083,066$. It is emphasized that this study is a subproject of an umbrella research entitled "Collective construction of protocols and manuals".

All the steps of this research were carried out in a Brazilian Unit of High Complexity Care in Oncology.

The participants were $29 \mathrm{FCs}$ of people with malignant neoplasia hospitalized in an oncology sector. In this sector of hospitalizations, the number of family caregivers is representative and the most varied family arrangements for the follow-up of the loved family member are found.

The number of family caregivers, initially, was not delimited, but rather defined from the analysis of the interviews until theoretical saturation occurred. ${ }^{11}$ As the exploitation of the data was accomplished, new information was investigated, so that the categories were improved and deepened.

Based on convenience sampling, were adopted as inclusion criteria: being over 18 years of age, being FC of patients with malignant neoplasia (considered by the patient) and accompanying the family member during hospitalization. Exclusion criteria were: FC who was unable to participate at the time of collection and professional caregivers, that is, paid to accompany the patients.

Data collection took place in two stages: the first stage consisted of individual interviews, and the second was performed from four focus groups. Both were conducted in a private room in the study field, from September to November 2017. The interviews had an average duration of 20 minutes and the focus groups, of 60 minutes. The number of focus group participants ranged from six to nine FC.

In the focus groups were used colored ribbons, used to represent feelings, emotions and thoughts.

The choice of the method and techniques was defined by the best way to mobilize the family members, achieving a dynamic that did not alter the routine of the sector, nor did it bring harm to the patient. In view of this situation, it was decided to conduct an individual interview with guiding questions about the purpose of the study and with questions about the characterization of the participant and the relative, such as age, sex, marital status, education, degree of kinship with the patient, religion and spirituality, municipality of residence, family income, how many in the family work, whether the participant works and how many hours a day. Soon after, the focus groups were held with the FCs who agreed to participate in the research.

Two digital recorders were strategically positioned to better record the speeches. These were then transcribed and analyzed. The secrecy was maintained through the adoption of the letters $C$ (Caregiver), followed by the sequential number to the subsequent participations held $(\mathrm{C} 1, \mathrm{C} 2, \mathrm{C} 3, \ldots)$.
Data analysis was based on thematic analysis, that is, the analysis of models to be reproduced within the elements, in which the issues that arise are divided into categories. ${ }^{12}$ There are multiple ways of approaching within this analysis, through which it is possible to emphasize the deductive, based initially on template (models of codes) and; the inductive one, driven by the information. In this study, a hybrid model was selected, that is, that groups the inductive and the deductive. ${ }^{1,12}$ Thus, initially, the data were analyzed in an inductive way, establishing codes and initial topics and, afterwards, was applied the template (in this research we used the premises of Vygotsky's socio-constructivism and the theoretical framework of the construction of resilience processes) with the purpose of identifying meaningful units of text also in a deductive way.

\section{RESULTS}

The patients assisted by FC had an average age of 55.3 years and presented a medical diagnosis of head and neck, gastrointestinal, pulmonary, gynecological and hematological cancer. All had complications due to the disease, making clear the need for great disposition and solidarity on the part of family caregivers.

It should be pointed out that the FC, three times a week, three of the researchers of this study, being one a clinical psychologist, one a nurse Ph.D. in Psychiatric Nursing and another an oncology nurse, carried out group dynamics in the years 2017 and 2018 and, whenever necessary, individual care, in order to clarify the doubts of the family and patient, as well as help in coping with the difficulties experienced during hospitalization and in the execution of the care.

The 29 family caregivers were mostly female (19), in the position of wife (9) and husband (1), daughter (2) and son (4), brother (2) and sister (2), nephew (2), sister-in-law (2), cousin (1), mother (1), grandmother (1), friend (1) and colleague (1), average age of 50.8 years.

The analysis of the narratives, according to the premises of Vygotsky's theoretical constructivism and the construction of the processes of resilience, showed memorable moments. These approaches were chosen because they recognize that the meanings of actions for the individual rest on the lived experience; therefore, three thematic categories were identified: "feelings revealed through colors"; "practice of care and communication in the process of resilience" and "faith and hope in the process of resilience".

\section{Feelings revealed through colors}

With the dynamics of colored ribbons, the choice of many black ribbons has emerged, which, in many cultures, mean denial and fear. In many countries of America and Europe it is associated with death and mourning, as well as with pain and fear, as evidenced by the following: 
[...] I chose this black one because it's complicated when we get bad news, right? When my mother told me, the first thing I thought, she was going to die. But it's already been two and a half years that we are fighting! (C2).

[...] the black ribbon, because the treatment is difficult, there are many ups and downs, twice I thought she could not take it [...] almost died a few times (C6).

The color representativeness varied for each participant. Each FC, when viewing a color, accessed in the unconscious different feelings and impressions:

[...] I chose purple because when I discovered that my husband was with this disease I was very sad, so I think, that for me, everything would end, you know? That is why I cannot speak [...] (C9).

[...] purple, because my life has also changed a lot, because my husband is a businessperson. He had a stroke in the back of his eye, then the bowel cancer, then the liver metastasis. So he cannot work anymore, and it is financially difficult for my entire family [...] (C18).

[...] I chose white because it represents peace, harmony, tranquility. So, along with that, love! Therefore, the firmness, that everything you believe to be strong, that the white color symbolizes [...] (C26).

[...] green is hope, green is hope! And white is peace! And that is why! I do not know if it's all that! But, that's why! (C12).

[...] red means this love and I want to give all love and affection to him, at that moment is what he needs most. White to give peace to me and for everyone in my family (C19)

[...] lilac, because of my radical change! I don't even know how to explain! My life has changed a lot [...] it's been two months that I haven't worked, I do nothing else [...] I am living in the hospital, it has been 54 days and I slept at home five days. So it has changed a lot, financially difficult, but lilac is said to by transmutation, I am transforming myself into a different person, stronger and with more faith! (C24).

\section{Practice of care and communication in the process of resilience}

Often, a family member, with greater leadership, took care of and did not share the tasks. In others, the assistance was shared, as it was verified in the statements below:

[...] I'm staying with my mother, it's been about fifteen days. We change, tomorrow I leave and my brother comes. Then, Monday, l'll be back. Next week she might be discharged [...] (C29).
[...] we take turns, it's not that everyone can sleep, but being here during the day... just as we who spend the night ... we treat people better, we have more contact [...] (C22).

[...] my sister is taking turns, we stay during the day. I'll even stay the night for her to rest (C16).

Coherence is important for family members as it allows for mutual support, collaboration and commitment. It is necessary that FCs respect and define the needs and limits of each one, so as not to generate overload and stress of this caregiver, even if it assists in the capacity of the $\mathrm{FC}$ to resist adversity and to use it as a growth factor:

[...] I am more ignorant in my house, more difficult to deal with, and I was who my mother chose to stay. I stay [...] I think what she is going through will serve me, for the rest of my life [...] I got tired and now we share, we are three rotating, but I have taken it as a mission [... . (C15).

[...] I spent 66 days in hospital with him. Twenty-four hours vigilant. I did not go home to take a shower. My daughter brought clean clothes for me [...] I did not trust anyone to stay with him, I did not trust [...] but today I am stronger and a better person (C26).

[...] it's not lack of confidence, I'm very attached! It was always party together, church together. Now, at these times, we also have to show ourselves [...] stay together, as long as I can, I want to take care of her and it helped me to be a better person and more resistant to the stumbles of life (C25).

Concerning communication, it has to be clear, with consistent words and actions. The clarifications on the treatment of malignant neoplasm need to be truthful and simple on the part of health professionals so that the family can have clear and true ideas of the disease and define the best path to follow. However, this assertiveness was not always perceived:

[...] you see the diagnosis, it is clear! The doctor says that your illness is serious. We are going to work your quality of life ... the doctor says only that! (C17).

[...] purple are the doubts, the worries, because comes about the worries, the issue of responsibility, if it is going right. If the doctors are doing it right [...] (C21)

[...] the doctor gave two days to my mother, only! He called me and said I was stronger. They started postponing her surgery, she got very bad in our city [...] another doctor operated her and, today, here she is [...] (C25).

The communication used for prevention campaigns against the most varied types of cancer, performed by the health institution where the study was developed appeared in the speeches of caregivers: 
[...] Pink is, as I can tell, I remembered the cancer association campaign (October campaign for breast cancer prevention). That's all I have to say ... to say, that's it, for all of us to have a lot of strength, peace and health (C3).

[...] blue because of cancer hospital staff, the color means ... the campaign they do (campaign held to prevent prostate cancer). I think blue is hope, so, a lot of hope[...] (C11).

\section{Faith and hope in the process of resilience}

Faith, that is, a sense of total belief in some higher force or superior being were important influences in the process of resilience. The FCs could attribute some sense to adversity, providing contextualization of the situation, understanding and managing possible solutions, as can be seen in the words:

[...] I am here accompanying her, I have a lot of faith and I believe in God, even though I do not have a religion, I believe in God helping me overcome all difficulties [...] helping to understand the reason for everything we are going through. [...] (C9).

[...] I am very religious, I go to the prayer group, you have to believe in God! Because I live a terrible moment, wow, it was not easy! God will heal. God blessed and everything went well! I ask no one to falter in faith! The only thing we have is faith [...] (C25).

[...] I believe in an inner strength that we all have and we discover in difficult times like that of this bad disease [...] this force helps me to reduce anxiety and to stay here helping to care $[. .].(\mathrm{C} 5)$.

Faith was able to alleviate suffering, to bring hope, to show alternative ways, to mobilize the FC to act in order to overcome pain and not allow oneself to succumb to suffering:

[...] God willing we will yet have a joy. Because now we have gone through a difficult time [...] only God and the hands of the doctors [...] I have hope that He will heal, I stopped just lamenting and crying everywhere (C20).

[...] hope is the last that dies, if there is a sigh, a breath, then there is hope and today I think I understand life more [...] I am doing nursing technical course, I discovered that I love to take care of people (C26).

[...] faith in God gave me hope and helped me to see that life otherwise [...] this disease made me see the world in another way and stop making a mountain out of a molehill, it's not just money, buying, showing off to others [...] today I look at people for what they are, I'm stronger (C4)

It was noticed that the $\mathrm{FC}$ who was able to talk about his feelings concerning malignant neoplasia, presented more ease in dealing with the stressor moment and managed to give more strength to his relative:

[...] if you hear laughter deep down there, it's me, my mother, and the nurse who works here, we talk, we make jokes, and we often cry together when we talk about our sorrows (C25).

[...] I drank and used drugs, I was sick [...] I found help taking care of her, she gave me strength [...] talking about my sufferings with her [...] I left these bad things [...] I helped her and she helped me! (C10).

[...] here is a teaching for our lives! No use pride, no use at all! Every day that passes, we have become more mature with suffering and this is very good, we become better people (C20).

The proactive approach was fundamental, since it made possible crisis resolutions. It was noted that caregivers made several arrangements in the family to cope with the disease:

$[\ldots]$ for me here $[\ldots]$ being united gives us strength [...] this strength is what is necessary in the family. Just as I said that being united makes us strong, united family. We take turns, it is not that everyone can sleep, but being here during the day [...] (C22).

[...] we always want to help each other. Everything that we have discovered [...] if you need me, I am here for you! (C26).

[...] from January to this time I felt more human [...] helping is everything (C23).

It was also observed that if there were negative fantasies about the outcome of the treatment, there was also a feeling of hope and that in the end everything would work out:

[...] Hope green, brings a lot of hope, that we have hope that will win this fight $(\mathrm{C} 1)$.

[...] I have hope, that God will heal (C25)

\section{DISCUSSION}

In agreement with other studies, the described characteristics approximate themselves to the FC profile, which are women, with an average age of 50.8 years. The woman still has the role of caring for the children and of the entire family, and this care has already been institutionalized. ${ }^{2,13-14}$

In our society, the role of the caregiver woman is already expected, but it becomes crucial to be questioned, since it is not always a positive factor. In the case of patients with malignant neoplasia, a heavy burden is usually observed, which requires support and help from other relatives. ${ }^{2}$ 
However, it is important to note that, about the difference of the resilience potential from the perspective of the gender variable, in the literature, the consensus was not possible to verify the difference in the individuals until the present moment. ${ }^{15}$

It is emphasized that the friend and the colleague were considered by the patients as members of their family by affective attachment for several years and were FC of the same. The study points out that, regardless of their structure, their links are consanguineous, of alliance, or family life coexistence, that have the function of integrating and organizing the development of their members, and are directly related to the increase of resilience potential. ${ }^{7}$

In relation to the dynamics of the colored ribbons, the color expressed feelings for each person who contemplated it, representing feelings, emotions and thoughts. In addition, Vygotsky characterized the use of instruments and signs as activities that served as an intermediary, which guide the behavior of people, in the unconscious incorporation of certain attitudes and; the colors are like signs, that is, it is indispensable that the meaning of the sign reaches out to the people in some way and that the person has the opportunity to verify if the meaning he/she has captured, reconstructed internally, is socially shared. ${ }^{9}$

In this sense, it is emphasized that visual perception is subject to factors such as the brain and the optical system and has a different language according to their experiences since childhood, and can have positive or negative meanings. ${ }^{16}$

Corroborating with the literature, which states that color is like speech and sound; inevitable and representatives of feelings and actions; all colors have connotations whether negative or positive. ${ }^{14}$

The colors brought a unique significance to each individual, reflecting their cultural experiences, and knowledge acquired throughout life. The importance of the dynamics used in this study for the mobilization of the caregivers is emphasized, so that, from the guiding questions, they expressed their feelings regarding the stressful moment they lived.

Concerning the meanings of the signs, the family context is of fundamental importance. The meanings of signs arise from interactions with the external environment, with the other, in the most diverse situations of conflict and stress. ${ }^{2}$ At these moments, people are constructing ways to deal with the stressor and socially sharing their feelings, which are part of their process of resilience. ${ }^{8}$

In this perspective, the individual becomes more vulnerable and his/her bonds, more fragile in situations of conflict, having the family a fundamental role in finding new strategies and maintaining hope. So that the family becomes resilient and able to give the patient the tranquility he/she needs, which is often only to find the balance between personal life and the demands that the treatment imposes on the FC. ${ }^{17-18}$

It was observed that cancer was a disease that demanded much from the family, causing many FCs to feel overwhelmed, having at some point to give up work and social activities. In this process, the family feels anxious, stressed out because of financial problems. Given this, interventions are necessary, such as educational programs, to guide the family on the course of treatment and about coping with the disease, empowering the FC in their process of resilience. ${ }^{2,6}$

It should be noted that the most important social sharing was the family, being an essential social support network among its members, followed by the community. Studies show that family support in times of stress is fundamental in the search for solutions and handling of a disease,,$^{3-4,19-22}$ such as cancer.

Coherence is important for family members of a person under treatment for malignant neoplasia, since mutual support, cooperation, and commitment occur. However, it is imperative that the FCs respect and jointly determine the needs and limits of each one, in order to not generate overload in some member, contributing to the stressful and becoming a vulnerability in the process of resilience.

It is emphasized that a circumstance of fragility indicates the viability of singular or collective paths leading to unwanted outcomes. ${ }^{23}$ However, there is no causal relation between a circumstance of indefeasibility and processes of weakness. ${ }^{18,23}$ In the course of illness, it is not always credible to foretell the outcome or the consequences of an aggravation. In the face of such events, is expected what is acceptable or admissible. The experience calls for caution and the paths and endings are always multiple. ${ }^{23}$

Within this context, it is known that the fragility and resilient propensity coexist. It is the same person who experiences them. One acts as a condition of possibility of the other; the two belong to the same existence. Resilience refers to continuation, testing of variables, reiteration, without admitting the vulnerability that is intrinsic to the individual. ${ }^{19,23}$

Regarding the protection factors arising from the resilience process, these were associated with family reality and the context of meanings shared among its members. According to the constructivist position, the individual constructs his/her vision of the environment in which he/she lives based on his/her subjectivity, desires and life story. ${ }^{8-9}$ It is the subjective aspects that will define the individual's way of managing a moment of conflict and develop coping mechanisms, that is, their process of resilience. ${ }^{17}$

It was verified that the family was the support of the patient and the arrival of this diagnosis of cancer was received with suffering and despair, causing a crisis in the family context, corroborating with the literature. ${ }^{19}$

Organizational patterns are defined by: flexibility, cohesion, and social and economic resources. Flexibility allows the openness to changes in the family environment, making each individual reorganize to have a continuity in their daily lives. Families organize themselves in different ways, some of which work with caregivers, and others do not. ${ }^{17-19}$

It was observed in the speeches of the FC that occupying this role is seen as a mission, or by the fear of the other not caring properly. Mostly, the one with the power of greater 
leadership takes care of the treatment and accompanies his/ her family member in consultations, exams and hospitalization. The caregiver's choice is identified by the request of the family member who is ill, who feels more comfortable or safe with the same. ${ }^{2}$

Organizational patterns are associated with conflict management, mutual support, commitment, and respect. Leadership in the family group was also important because it is the leader who has guided and protected the most vulnerable members of the family. The leader acts as moderator of family relationships and organizes the environment more adequately. ${ }^{8} \mathrm{It}$ has been found in the FC group that leaders organize and take responsibility for care.

Regarding the communication between FCs and patients with malignant neoplasia and health professionals, effective communication was fundamental, corroborating with a study that states that only providing data about cancer and care is insufficient; it is necessary that the health specialist be able to transmit the information and give the correct importance to the communication so that the link is established. ${ }^{2}$

Language is a sign, and through language, we can organize practical activities and psychological functions. Practical activities involve the collective, the system in which the individual lives. ${ }^{9}$ This is where this individual speaks, using what has been internalized in his/her collective life, using his/her culture, beliefs and religiosity. ${ }^{19}$

In this regard, it becomes paramount to consider that it is imperative that a team of professionals from various areas, and not just the doctor, dialogue with the patient and the family to elucidate inaccuracies about treatment and illness. The lack of clarity of this information can lead to distress, refusal to treatment and increased morbidity. ${ }^{20}$

It was noticed in the caregivers' discourses that the malignant neoplasia represented collectively a fatal disease and of difficult cure. In the explanations, it was observed the disease with frightening dimensions and it was noticed the need for a clearer language for the disease to be demystified and to empower the $\mathrm{FC}$ in the care process. ${ }^{2,18}$

The speeches showed that health promotion and prevention campaigns were important. Educational campaigns need to be increasingly used to make the language of the disease clearer and more natural, with less frightening meaning, facilitating family resilience processes in the dealing with cancer.

Research indicates that the possibility of having technical and scientific knowledge, coupled with the growing educational coefficient of individuals, has an impact on people seeking clarification before consulting the specialist in the health sector. ${ }^{2,21}$ Thus, with the increasing availability of news and reports, especially through the internet, a transformation in the behavior of nurses and other health professionals is necessary to serve these clients/patients, adopting a more open attitude. ${ }^{21}$

As for religious beliefs and spirituality, faith was paramount in strengthening and balancing FCs; appeared as a point of satisfaction and comfort for the difficult times, often overwhelming, thus being an important ally to people in distress.
Spirituality has been tried in different ways. For some, it involved active participation in a religion, where, through faith in a God, they sought the hope and inner strength they need to face this painful event; for others, it was related to an internal spiritual force. Both, in a way, allowed giving meaning to the painful experiences, which was a way of channeling anxieties and the fear of death.

Faith and resilience are ways that families and patients discover as a source of support for dealing with malignant neoplasia, in the same way, to cope with the challenges prompted by treatments, or even to comfort themselves with finitude. ${ }^{22}$ Thus, resilience and faith become a very important instrument for the family and the patient in facing the process of illness, due to the capacity to provide relief, comfort and hope in overcoming the obstacles imposed by the illness. .2-23 $^{2}$

It was noted in the speeches of the FCs a construction based on faith and religiosity, making the difficult moments become bearable, with the possibility of overcoming. Research carried out in Minas Gerais on spirituality, religiosity in the face of cancer, states that these factors can cause relief, provoke feelings of faith, reduce stress, besides being an additional agent in the process of resilience, increasing the quality of life $^{24}$, as observed in the speeches of the participants of this study.

Spirituality is understood by most scholars as an intrinsic characteristic of the human being, who seeks sense and meaning for existence and considers factors such as the level of personal knowledge, recognition of a universal truth or a higher power capable of referring us to a sensation of wholeness and well-being with the world. ${ }^{22} \mathrm{As}$ such, spirituality has been pointed out as the cornerstone of resilience, capable of promoting and mediating it. 19,22

According to studies, the relative of the person with malignant neoplasia needs to develop coping strategies to deal with the disease. ${ }^{2}$ Religion, faith and prayers are strategies used by the family of cancer patients and many become more religious after the diagnosis of the disease. 22,24

Thus, in caring for the cancer patient, the family plays an important role, since it is pointed out, along with faith, a primordial source of support for the patient and holds responsibility for their physical, emotional and social well-being. This task can bring personal gains, such as the discovery of inner strength previously unknown; however, it becomes exhausting for the family caregiver, since it distances him/her from his/her routine activities, leads to financial expenses, deprivation of social contact and continuous contact with pain and suffering. ${ }^{2,18}$

Therefore, the health team needs to develop attitudes such as being interested in and empathy towards others, being open to discussing finiteness, faith, encouragement, hope, and all that is needed, thus listening attentively, showing trust and honesty. ${ }^{23}$

The human being has autonomy, creativity and is an active being. Has possibilities to create strategies in moments of crisis, to transform suffering and pain into positive solutions. ${ }^{6,9,25} \mathrm{In}$ FC's speeches, the transformation of suffering into positive attitudes and emotions and a transmutation of negative feelings were observed. 
Resilience is an internal process of psychological adaptation, present in all individuals and applicable in any environment, whether unfavorable or not. Therefore, all people have the capacity for healthy and positive development. Studies have argued that individuals considered resilient do not use positive emotions only for themselves, but induce and instigate these emotions in others. ${ }^{16,21}$

The research also suggests that positive emotions undo the harmful effects of stress and contribute to health, increase the tendency to help others, providing new experiences and practices. $^{21}$

It was perceived that the connection between $\mathrm{FC}$ resilience and human development is undoubtedly, particularly for the reason that the former strengthens the potentialities and resources of families to overcome future crises and can activate the characteristics of the individual in the face of the situation of risk or adverse context. In this sequence, it is congruent to apprehend the development of the person because of the exchange of the essential attributes of the individual and of the environment. ${ }^{6}$

The results of this research show changes in the family arrangement of patients after the onset of malignant neoplasia and during its treatment. From a socio-constructivist point of view, the FCs presented flexibility for change in order to carry out the tasks that were expected, notably those of providing protection and support to their members. This matter pointed to healthy family structures, as the family members transformed and faced the challenges intrinsic to the disease and the treatment, which could contribute to the process of resilience of FCs, data also found in a study carried out in a cancer treatment hospital of Pernambuco, which aimed to understand how the family is organized to deal with the disease and the patient. ${ }^{26}$

The shock of illness struck the sick individual and his/her entire family. The vast majority of FCs who participated in this study established new rules around family subsystems and modified customs to adapt to the new existence and ensure uninterrupted common sense and well-being.

\section{CONCLUSIONS AND IMPLICATIONS FOR PRACTICE}

The findings show that the FCs participants in this study planned themselves in order to provide support to their family member with malignant neoplasia and, therefore, facing, in a more strengthened way, the transformations imposed by the disease. In this context, faced with the pressures imposed by the cancer illness of one of the members of their family, these FCs exhibited a more flexible conduct, which provided changes and a positive feedback in relation to the new charges, therefore being resilient.

In addition, communication with health professionals was paramount in the confronting of the family caregiver group when dealing with problems or conflicts and it was noticed that there is a better conduction in the process of illness of the loved one, in those FCs with greater knowledge and understanding of the disease.

Other factors that contributed to the FC's resilience process were the health worker's orientation, the emotional support received, and spirituality. Therefore, in order to effectively assist the family, the support of health professionals has become necessary.

As a limitation of this study it is mentioned that it does not allow the generalization of the results or establishment of cause and effect relationships, since it was performed with FCs of people with cancer from a single health institution. Another limitation was the context of institutionalized care, where FCs received scientific technical support from health professionals when they had any doubts about the care provided, clinical evolution or treatments, as well as group dynamics, which may have influenced the process of resilience.

It is hoped that this research can collaborate with researchers and professionals in the field of cancer, in the same way, awaken new studies in this field, which can leverage studies that contribute to the process of resilience in family caregivers of patients with malignant neoplasia, who not always are in search for the cure, but rather for the family well-being.

\section{REFERENCES}

1. Oliveira PP, Gesteira ECR, Silveira EAA, Amaral L, Moreira MMC, Rodrigues AB. Evaluation of families with two or more mastectomized women: a case study. Online Braz J Nurs [Internet]. 2016 Mar; [cited 2018 June 3]; 15(1):83-95. Available from: https://doi. org/10.17665/1676-4285.20165231

2. Mata LRF, Cunha AC, Ziviani CSL, Fonseca TG, Bernardes MFVG, Oliveira PP. Psychological morbidity and implications for the recovery of adults after oncology surgery. Cogitare Enferm [Internet].2018; [cited 2018 Sep 24]; (23)1:e53089. Available from: http://dx.doi.org/10.5380/ ce.v23i1.53089

3. Furtado MEMF, Leite DMC. Cuidados paliativos sob a ótica de familiares de pacientes com neoplasia de pulmão. Interface (Botucatu) [Internet] 2017 Feb; [cited 2018 June 30]; 21(63):969-80. Available from: http:// dx.doi.org/10.1590/1807-57622016.0582

4. Franco MHP. A família em psico-oncologia. In: Carvalho VA, Franco MHP, Kovács MJ, Liberato R, Macieira RC, Veit MT, et al., orgs. Temas em psico-oncologia. São Paulo: Summus; 2008. p. 358-61.

5. Borges EL, Franceschini J, Costa LHD, Fernandes ALG, Jamnik S, Santoro IL. Sobrecarga do cuidador familiar: a sobrecarga de cuidar de pacientes com câncer de pulmão, de acordo com o estágio do câncer e a qualidade de vida do paciente. J Bras Pneumol [Internet]. 2017 Jan/Feb; [cited 2018 June 30]; 43(1):18-23. Available from: http:// dx.doi.org/10.1590/S1806-37562016000000177

6. Manzini CSS, Vale FAC. Resilience of family caregivers of elderly with Alzheimer. Rev Eletr Enferm [Internet]. 2016; [cited 2018 Dec 19];18:e1190. Available from: https://doi.org/10.5216/ree.v18.37035

7. Manzini CSS, Brigola AG, Pavarini SCI, Vale FAC. Fatores associados à resiliência de cuidador familiar de pessoa com demência: revisão sistemática. Rev Bras Geriatr Gerontol [Internet]. 2016 Jul/Aug; [cited 2018 Dec 19]; 19(4):703-14. Available from: http://dx.doi. org/10.1590/1809-98232016019.150117

8. Yunes MAM, Szymanski H. Resiliência: noção, conceitos afins e considerações críticas. In: Tavares J, org. Resiliência e educação. $2^{a}$ ed. São Paulo: Cortez; 2001. p. 13-42. 
9. Vygotsky LS. A formação social da mente: o desenvolvimento dos processos psicológicos superiores. 6를 ed. São Paulo: Martins Fontes; 2001.

10. Yunes MAM. Psicologia Positiva e Resiliência: foco no indivíduo e na família. In: Aglio DDD, Koller SH, Yunes MAM, eds. Resiliência e Psicologia Positiva: Interfaces do Risco à Proteção. São Paulo: Casa do Psicólogo; 2006. p. 45-68.

11. Nascimento LCN, Souza TV, Oliveira ICS, Moraes JRMM, Aguiar RCB, Silva LF. Theoretical saturation in qualitative research: an experience report in interview with schoolchildren. Rev Bras Enferm [Internet]. 2018 Jan/Feb; [cited 2018 June 3]; 71(1):228-33. Available from: http://dx.doi. org/10.1590/0034-7167-2016-0616

12. Fereday J, Muir-Cochrane E. Demonstrating rigor using thematic analysis: a hybrid approach of inductive and deductive coding and the me development. Int J Qualit Methods [Internet]. 2006 Mar; [cited 2018 June 3]; 5(1):80-92. Available from: https://doi. org/10.1177/160940690600500107

13. Oliveira WT, Matsuda LM, Sales CA. Relationship between wellness and sociodemographic characteristics of caregivers of people with cancer. Invest Educ Enferm [Internet]. 2016; [cited 2018 Dec 19]; 34(1):128-36. Available from: $\mathrm{http}: / / \mathrm{dx}$.doi.org/10.17533/udea.iee.v34n1a15

14. Gomide GI. Cor e construção cultural. Rumores [Internet]. 2016 Jul; [cited 2018 Dec 19]; 10(19):42-57. Available from: https://doi.org/10.11606/ issn.1982-677X.rum.2016.111850

15. Carvalho RC, Bastos ACSB. Famílias e vulnerabilidades em saúde: questões teóricas, éticas e metodologias para intervenção. Rev Saúde Col UEFS, Feira de Santana. 2017 Sep; [cited 2018 Dec 29]; 7(2):72-4. Available from: $h$ ttp://dx.doi.org/10.13102/rscdauefs.v7i2.1785

16. Heller E. A psicologia das cores: como as cores afetam a emoção e a razão. 1a. ed. São Paulo: G Gilli; 2012

17. Oliveira KS, Nakano TC. Avaliação da resiliência em psicologia: revisão do cenário científico brasileiro. Psicol Pesqui (Juiz de Fora) [Internet]. 2018 Jan/Apr; [cited 2018 Dec 19]; 12(1):1-11. Available from: http:// dx.doi.org/10.24879/2018001200100283

18. Marchi JA, Paula CC, Girardon-Perlini NMO, Sales CA. The meaning of being-a-caregiver of a dependent relative suffering from cancer: palliative contributions. Texto Contexto Enferm [Internet]. 2016 Mar; [cited 2018 Dec 29]; 25(1):e0760014. Available from: http://dx.doi. org/10.1590/0104-07072016007600014
19. Young WC, Nadarajah SR, Skeath PR, Berger NA. Spirituality in the context of life-threatening illness and life-transforming change. Palliat Support Care [Internet]. 2015 Jun; [cited 2018 Dec 30]; 13(3):653-60. Available from: $h$ ttps://doi.org/10.1017/S1478951514000340

20. Hey AP, Caveião C, Motezeli JH, Visentin A, Takano TM, Buratti FMS Means of communication used by patients: information about cancer after diagnosis and during treatment. J Res Fundam Care. Online [Internet]. $2016 \mathrm{Jul} / \mathrm{Sep}$ [ [cited 2018 Dec 19]; 8(3):4697-703. Available from: http://dx.doi.org/10.9789/2175-5361.2016.v8i3.4697-4703

21. Costa RAS, Soares CCD, Silva JB, Silva VA, Ferreira JA. A comunicação entre enfermeiros e pacientes críticos masculinos: estratégia de enfrentamento. Rev Univ Vale do Rio Verde [Internet]. $2018 \mathrm{Jan} / \mathrm{Jul}$ [cited 2018 Dec 19]; 16(1):1-8. Available from: http://dx.doi.org/10.5892/ ruvrd.v16i1.3739

22. Soratto MT, Silva DM, Zugno PI, Daniel R. Espiritualidade e resiliência em pacientes oncológicos. Rev Saúde Pesq [Internet]. $2016 \mathrm{Jan} / \mathrm{Apr}$ [cited 2018 Dec 28]; 9(1):53-63. Available from: http://docs.bvsalud.org/ biblioref/2017/02/831994/6.pdf

23. Schuck LM, De Antoni $C$. Resiliência e vulnerabilidade nos sistemas ecológicos: envelhecimento e políticas públicas. Psicol Teor Pesq [Internet]. 2018 Jun; [cited 2018 Dec 28]; 34:e3442. Available from: http://dx.doi.org/10.1590/0102.3772e3442

24. Souza VM, Frizzo HCF, Paiva MHP, Bousso RS, Santos AS. Spirituality, religion and personal beliefs of adolescents with cancer. Rev Bras Enferm [Internet]. 2015 Sep/Oct; [cited 2018 Dec 19]; 68(5):791-6. Available from: http://dx.doi.org/10.1590/0034-7167.2015680504i

25. Oliveira MBP, Souza NR, Bushatsky M, Dâmaso BFR, Bezerra DM, Brito JA. Oncological homecare: family and caregiver perception of palliative care. Esc Anna Nery [Internet]. 2017; [cited 2018 Dec 23] 21(2):e20170030. Available from: http://dx.doi.org/10.5935/14148145.20170030

26. Melo MCB, Barros EN, Campello MCVA, Ferreira LQL, Rocha LLC, Silva CIMG, et al. O funcionamento familiar do paciente com câncer. Psicol Rev (Belo Horizonte) [Internet]. 2012 Apr; [cited 2019 Apr 29]; 18(1):7389. Available from: https://doi.org/10.5752/P.1678-9563.2012v18n1p73 